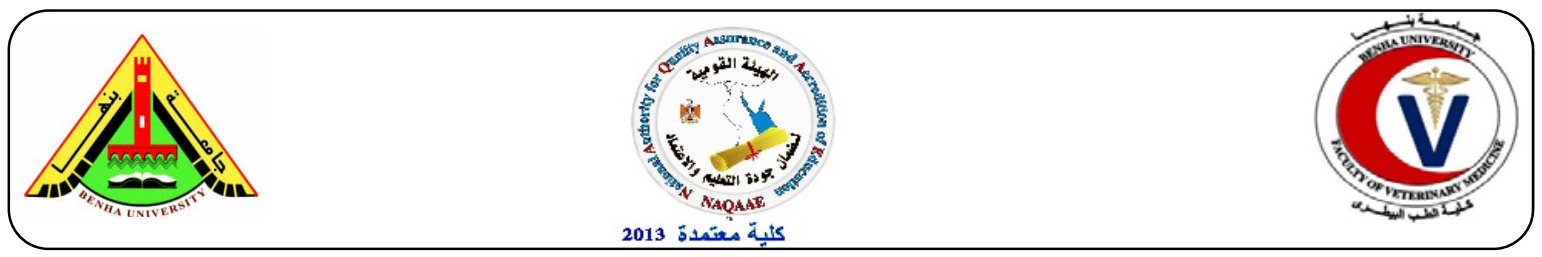

\title{
Incidence of Some Food Poisoning Microorganisms in Salted fish
}

\author{
Saad S.M ${ }^{1}$, Edris A.M ${ }^{1}$, Amani M. Salem ${ }^{1}$, Enas A. Hassan ${ }^{2}$, Eman M. Mostafa ${ }^{3}$ \\ ${ }^{1}$ Food Control Dept., Faculty of Veterinary Medicine, Benha University. ${ }^{2}$ Animal Health Research \\ Institute, Benha Branch. ${ }^{3}$ Kafr Shokr Veterinary Administration
}

\section{A B S T R A C T}

A grand total of 90 random samples of salted fish represented by salted sardine, salted Mugil cephalus (fesiekh) and salted Hydrocynus froskahlii (Mellouha) (30 of each) were collected from different supermarkets at El-Kalyoubia governorate. The collected samples were directly transferred to the laboratory for detection of Staphylococcus aureus and Clostridium perfringens as food poisoning microorganisms. The obtained results indicated that the mean values of Staphylococcus aureus count (cfu/g) in the examined samples of salted sardine, salted Mugil cephalus and salted Hydrocynus froskahlii were $9.77 \times 10^{2} \pm 2.01 \times 10^{2}, 4.25 \times 10^{2} \pm 0.58 \times 10^{2}$ and $0 / \mathrm{g}$, with an incidence of $73.33 \%$, $43.33 \%$ and $0 \%$ for the same examined samples, respectively. The obtained results revealed also that the mean values of Clostridium. perfringens ( $\mathrm{cfu} / \mathrm{g}$ ) in the examined samples of salted sardine, salted Mugil cephalus and salted hydrocynus froskahlii were $2.00 \times 10^{2}, 5.53 \times 10^{2} \pm 0.7 \times 10^{2}$ and $0 / \mathrm{g}$, with an incidence of $3.33 \%, 10 \%$ and $0 \%$, for the same examined samples, respectively.

Key words: Staphylococcus aureus - Clostridium perfringens, Salted fish.

(http://www.bvmj.bu.edu.eg)

(BVMJ-29(2): 225-229, 2015)

\section{INTRODUCTION}

$O$ alted fish products are popular in many countries around the world. Salting is one of the oldest techniques for fish preservation, and essentially intended to increase the shelf-life of the product through depressing water activity by dehydration and salt uptake by the fish muscle. In addition, Sodium chloride is a flavor enhancer as a consequence of its effect on different biochemical mechanisms by reducing or enhancing the enzymatic activity of some enzymes responsible for the development of different organoleptic parameters (Albarracin et al., 2011). However, the current demand for salted fish is driven more by the flavor of the product than for preservation purposes (Ali, Mariyam, 2012). Presence of Staphylococcus aureus in a food indicates its contamination from the skin, mouth and/or nose of food handlers. Inadequately cleaned equipment may be a source of contamination (Thatcher and Clark, 1978). Staphylococcus aureus is still a major cause of food poisoning due to ingestion of enterotoxins (Stengel, 1990). The ability to produce such enterotoxin in food is more likely when competing microorganisms were absent (Frazier and Westhoff, 1984). Clostridium perfringens spores can reach fish and shellfish in their water habitat (particularly near sewage outfalls), from surfaces of holds in vessels, equipment and utensils used for processing and preparation or from workers. Counts greater than $10^{6}$ $\mathrm{cfu} / \mathrm{g}$ are necessary to cause illness; such quantities do not reach foods through mere contamination, but accumulate as a result of multiplication of vegetative cells (Bryan, 1980). The present study was carried out to determine the counts of Staphylococcus aureus and Clostridium perfringens in some marketed salted fish (salted sardine, salted 
Mugil cephalus and salted Hydrocynus Forskalii).

\section{MATERIAL AND METHODS}

\subsection{Collection of samples:}

A total of 90 random samples of salted fish represented by salted sardine, salted Mugil cephalus (Fesiekh) and salted Hydrocynus froskahlii (mellouha) (30 of each) were collected from different supermarkets at ElKalyoubia governorate. The samples were directly transferred to the laboratory for count and detection of Staphylococcus aureus and Clostridium perfringens counts.

\subsection{Preparation of samples}

It was done according to the technique recommended by ICMSF (1978).

2.3. Determination of Staphylococcus. aureus count according to ICMSF (1996).

2.4. Determination of Clostridium. perfringens count was done according to Harmon and Kautter (1978).

\section{RESULTS}

Table 1 revealed that the mean counts of Staphylococcus aureus cfu/g in the examined samples of salted sardine, salted Mugil cephalus (fesiekh) and salted Hydrocynus roskahlii (Mellouha) were 9.77 $\times 10^{2} \pm 2.01 \times 10^{2}, 4.25 \times 10^{2} \pm 0.58 \times 10^{2}$ and $0 / g$, respectively. Table 2 showed that there are significant differences between the examined samples of salted fish at $(P<0.01)$ according to their Staphylococcus. aureus count. Table 3 showed that the mean counts of Clostridium perfringens in the examined samples of salted sardine, salted Mugil Cephalus (Fesiekh) and salted Hydrocynus froskahlii (Mellouha) were $2.00 \times 10^{2}, 5.53$ $\times 10^{2} \pm 0.7 \times 10^{2}$ and $0 / \mathrm{g} c f u / g$ respectively. Table 4 revealed that the differences between the examined samples of salted fish were highly significant at $(P<0.01)$ according to the count of Clostridium perfringens.

Table (1): Statistical analytical results of Staphylococcus aureus count cfu/g in the examined samples of salted fish $(n=30)$.

\begin{tabular}{lccccc}
\hline Salted Fish & \multicolumn{3}{c}{+ ve samples } & & \\
& No. & $\%$ & Min & Max & Mean \pm S.E* \\
\hline Sardine & 22 & 73.33 & $1.0 \times 10^{2}$ & $3.0 \times 10^{3}$ & $9.77 \times 10^{2} \pm 2.01 \times 10^{2}$ \\
Mugil. cephalus & 13 & 43.33 & $1.0 \times 10^{2}$ & $1.2 \times 10^{3}$ & $4.25 \times 10^{2} \pm 0.58 \times 10^{2}$ \\
Hydrocynus froskahlii & 0 & 0 & 0 & 0 & 0 \\
\hline S.E*= Standard error of mean & & & &
\end{tabular}

Table (2): Analysis of variance (ANOVA) of Staphylococcus aureus count in the examined samples of salted fish

\begin{tabular}{lcccc}
\hline Source of variance & D.F & S.S & M.S & F. value \\
\hline Total & 89 & 16183.21 & & \\
Between Products (T) & 2 & 2704.95 & 1352.48 & $8.73^{++}$ \\
Error & 87 & 13478.26 & 154.92 & \\
\hline
\end{tabular}

D.F $=$ Degrees of freedom. S.S $=$ Sum squares. M.S $=$ Mean squares. $++=$ High significant differences $(P<0.01)$ 
Table (3): Statistical analytical results of Clostridium perfringens count $\mathrm{cfu} / \mathrm{g}$ in the examined samples of salted fish $(n=30)$.

\begin{tabular}{lccccc}
\hline Salted Fish & \multicolumn{2}{c}{+ ve samples } & Min & Max & Mean \pm S.E* \\
& No. & $\%$ & & & \\
\hline Sardine & 1 & 3.33 & - & - & $2.00 \times 10^{2}$ \\
Mugil. cephalus & 3 & 10.00 & $1.0 \times 10^{2}$ & $1.0 \times 10^{3}$ & $5.53 \times 10^{2} \pm 0.71 \times 10^{2}$ \\
$\begin{array}{l}\text { Hydrocynus } \\
\text { froskahlii }\end{array}$ & 0 & 0 & 0 & 0 & 0 \\
\hline
\end{tabular}

Table (4): Analysis of variance (ANOVA) of Clostridium perfringens count in the examined samples of salted fish

\begin{tabular}{lcccc}
\hline Source of variance & D.F & S.S & M.S & F. value \\
\hline Total & 89 & 12249.55 & & \\
Between Products (T) & 2 & 2995.36 & 1497.68 & $14.08^{++}$ \\
Error & 87 & 9254.19 & 106.37 & \\
\hline
\end{tabular}

D.F $=$ Degrees of freedom. S.S $=$ Sum squares. M.S $=$ Mean squares. $++=$ High significant differences $(P<0.01)$

\section{DISCUSSION}

Results achieved in Table (1) revealed that the mean counts of Staphylococcus aureus $c f u / g$ in the examined samples of salted sardine, salted Mugil cephalus (fesiekh) and salted Hydrocynus roskahlii (Mellouha) were $9.77 \times 10^{2} \pm 2.01 \times 10^{2}, 4.25 \times 10^{2} \pm$ $0.58 \times 10^{2}$ and $0 / \mathrm{g}$, respectively.

There are significant differences between the examined samples of salted fish at $(P<0.01)$ according to their Staphylococcus aureus count (Table 2). Table (3) showed that the mean counts of Clostridium. perfringens $c f u / g$ in the examined samples of salted sardine, salted Mugil Cephalus (Fesiekh) and salted Hydrocynus froskahlii (Mellouha) were $2.00 \times 10^{2}, 5.53 \times 10^{2} \pm$ $0.7 \times 10^{2}$ and $0 / \mathrm{g}$, respectively. The differences between the examined samples of salted fish were highly significant at $(P<0.01)$ according to the count of Clostridium perfringens (Table 4). The obtained results in the present paper concluded that the examined samples of salted sardine and salted Mugil cephalus were more contaminated with Staphylococcus aureus and Clostridium perfringens than salted Hydrocynus froskahlii. The presence of Staphylococcus areus in The examined salted fish samples suggested the poor personal hygiene of food handlers as well as the organisms may originate from suppurating lesions or from the carrier nostril (Elwi, 1994). The recorded results of Staphylococcus aureus count in table (1) were nearly similar to those recorded by Nayel (2007) and Youssef (2011), while Morshdy (1980) and Bashir and Agab (1987) reported higher results. The presence of Staphylococcus aureus in salted fish may lead to symptoms of Staphylococcal intoxication which appear within 2-4 hours following consumption of contaminated food (Bergdoll, 1979). Commonly reported symptoms include, nausea, vomiting and less frequently diarrhea, headache, dizziness, with few reported deaths in elderly or very young persons (Varnam, 1991). Clostridium perfringens spores can reach fish and shellfish in their water habitat (particularly near sewage outfalls), from surfaces of holds in vessels, equipment and utensils used for processing and preparation or from workers. Greater counts than $10^{6}$ $\mathrm{cfu} / \mathrm{g}$ are necessary to cause illness, such 
quantities do not reach foods by mere contamination, but accumulate as a result of multiplication of vegetative cells (Bryan, 1980). Regarding to the count of Clostridium. perfringens in, Table (3) indicated that the results of the present paper were lower than those reported by Nayel (2007) who revealed that Clostridium perfringens count were detected in $24 \%$ of the examined salted sardine samples and $36 \%$ of the examined salted Mugil cephalus (Fesiekh) samples; Lower results were obtained by Lela-Radwa (2012) who failed to detect Clostridium perfringens from all the examined salted samples. In order to control these microorganisms to gain access to salted fish products, and to improve the sanitary status of salted fish processing, periodical medical examination of persons sharing in processing, handling, transporting and salting of fish should be practiced. Licenses should be given to well hygienic fish markets. As well as application and implantation of hazard Analysis and Critical Control Point (HACCP) system in all points of fish manufacturing as a hazardous control system must be applied to ensure maximum safety to consumers.

\section{REFERENCES}

Albarracin, W., Sanchrz, I.C, Grau, R, Barat, J.M. 2011. Salt in food processing; usage and reduction; a review. Int. J. of Food Sci. and Technol., 46(7):1329-1336.

Ali, Mariyam 2012. Shelf life determination of the brined Golden mullet during vacuum refrigerated storage using some quality aspect; Acta Scientiarum PolonorumTechnologia Alimmetaria, 11(1):3743.

Bashir, El-R., Agab, M.A. 1987. Traditional salted fish with special reference to fesseikh. Faculty of Agriculture, Food Research Centre and Unesco Regional Training Course on Fermented Foods of the
Arab World, 1-5 February, Shambat, Khartoum, Sudan. 11p.

Bergdoll, M.S. 1979. Staphylococcal intoxication. In: Food borne intoxication. Eds. Reimann, H. and Bryan, F.L., Acad. Press. New York.

Bryan, F.L. 1980. Epidemiology of foodborne disease transmitted by fish, shellfish and marine crustaceans in the United States, 1970-1978. J. Food Protect. 43:859-879.

Elwi, E.M. 1994. Sanitary importance of meat meals in governmental hospitals in Assuit City. Ph.D. Thesis. Faculty of Veterinary Medicine, Assuit University. Egypt.

Frazier, W.C., Westhoff, D.C. 1984. Food microbiology $4^{\text {th }}$ Ed Tata McGraw Hill Publishing Co. Limited, New York, U.S.A.

Harmon, S.M., Kautter, D.A. 1978. Media for confirming Clostridium perfringens from food and feces $\mathrm{J}$. Food protect. 41:626-630.

International Committee on Microbiological Specification for foods (ICMSF). 1978. Microorganisms in foods. Their significance and methods of enumeration. $\quad 2^{\text {nd }} E d$., Univ. of Toronto press. Toronto, Canada

International Committee on Microbiological Specification for Foods (ICMSF). 1996. Microorganisms in foods. Microbiological specification of food pathogens. Blackie Academic and Professional. An Imprint Chapman and Hall, London.

Lela, Radwa, A.M. 2012. Microbiological studies on some fish products. M.V.Sc. Meat Hygiene Thesis (Food control), Fac. of Vet. Med., Benha Univ., Egypt.

Morshdy, A.M. 1980. Studies on the sanitary condition of salted fish marketed in sharkia. M.V.Sc. Thesis, Faculty of Vet. Medicine, Meat Hygiene, Zagazig University, Egypt. 
Nayel, M.S.Kh. 2007. Microbiological Status of Some Marketed Canned and Pickeled Fish. M.V.Sc Thesis (Food Control) Fac. Vet. Med., Moshtohor, Benha University, Egypt.

Stengel, G.F. 1990. Staphylococci. Fleischwirtschaft 70(3):307-312.

Thatcher, F.S., Clark, D.S. 1978. ICMSF, Microorganisms in foods. I, their significance and method of enumeration. Academic Press, New York.

Varnam, A.H. 1991. Food borne pathogens/Chapter, 4,5, 7 and 24 Wolf Publishing Ltd.

Youssef, A.K. 2011. Effect of Salting Processes on Mycological Status of Fish. M.V.Sc. Thesis, Dept. Food Control, Fac. Vet. Med. Assiut University, Egypt. 